\title{
Effect of project role, age and gender differences on the formation and revision of project decision judgements
}

\author{
Udechukwu Ojiako* \\ University of Johannesburg, South Africa \\ *(uojiako@yahoo.ca) \\ Maxwell Chipulu \\ University of Southampton, United Kingdom \\ (m.chipulu@soton.ac.uk) \\ Paul Gardiner
}

The British University in Dubai, United Arab Emirates

(paul.gardiner@buid.ac.ae)

Terry Williams

University of Hull, United Kingdom

(terry.williams@hull.ac.uk)

Caroline Mota

Universidade Federal de Pernambuco, Brasil

(carol3m@gmail.com)

Stuart Maguire

University of Sheffield, United Kingdom

(s.maguire@sheffield.ac.uk)

Yongyi Shou

Zhejiang University, China

(yshou@zju.edu.cn)

Teta Stamati

National and Kapodistrian University of Athens

(teta@di.uoa.gr)

\begin{abstract}
In this study, the authors examine how demographic variables such as project role, age and gender moderate the formation and revision of explicit decision judgements in a project by practitioners over the lifecycle of that project. Understanding the impact of these moderating factors on decisions made by project management practitioners can contribute to more effective managerial decision making; for example when decisions are being taken on whether or not to abandon a project. Empirical data are obtained from a quantitative survey of 1313 project
\end{abstract}


management practitioners across seven countries. Data analysis is undertaken using log-linear modelling in SAS9.2. The results show that while project role and age of practitioners served as influencing factors when forming or revising decision judgements at any stage in the lifecycle, gender was not found to show any significant effect ${ }^{1}$.

Keywords: Project Management; Decision judgement

\section{Introduction}

A primary tenet of project team management theory is the need to facilitate group decision making and to manage expectations. Earlier researchers have demonstrated that both practitioners (defined for the purpose of this study as an individual actively engaged in the discipline or profession of project management) and organisational factors impact on the effectiveness of groupdecision making (Schuler, 1980). For example, the effectiveness of the practitioner during groupdecision making is affected by tacit knowledge (Koskinen et al., 2003), professional ability (Hodgson, 2002; Cheng et al., 2005), personality and emotional intelligence (Clarke, 2010), and decision judgements (Fowler and Walsh, 1999). This research focused on practitioner decision judgements by investigating moderating factors (project role, age and gender) that are likely to impact on expressed judgements on success or failure of the project throughout the project lifecycle.

An understanding of when the decision judgements of practitioners on project success and failure are formed and revised is critical to project management because not only will awareness of judgements influence communication structures within the project, but it will also influence power relationships within the project team. Hence, differences in decision judgements, if not understood, may lead to substantial misunderstandings within the project team as well as suboptimal decision making.

\section{Decision judgements in projects}

\subsection{Stakeholder decisions in projects}

${ }^{1}$ The authors extend their appreciation to Dr Jaw-Kai Wang of the University of Southampton, Professor Christine Raisanen, Chalmers University of Technology and Dr Paul Chan of the University of Manchester for their comments on the initial draft of this manuscript. 
This study is heavily influenced by two major areas of research. The first relates to cognition and more specifically, the impact of demographic variables such as project age and gender (see Kidwell et al., 1987; Stern et al., 1993; Czaja et al., 1995; Davidson and Freudenburg, 1996; Powell and Ansic, 1997; Gustafson, 1998; Klenke, 2003; Mellahi and Guermat, 2004; Obst et al., 2011; Foschi and Valenzuela, 2012) and role differences (Srivastva, 1983; Johnson and Powell, 1994; Fowler and Walsh, 1999) on decision making. The second relates to the existence of different and sometimes conflicting perceptions of projects among different stakeholders.

A review of the literature shows increasing interest among project management scholars as it relates to decision making. However, an aspect of behavioural research which may not have been consistently and fully articulated is that of decision judgements as they relate to the mental attitudes that enable individuals to articulate their experiences of a particular phenomenon (Prinz, 1997; Freeman, 2003). While decision judgements are often conscious (Marcel, 1983a, 1983b; Cheesman and Merikle, 1986), i.e. explicit, they may also be implicit or non-conscious (Schacter, 1990). Decision judgements are generally manifest and are expressed by an individual through sensory stimulants such as sight, hearing, smell, taste and feelings (Bruner and Postman, 1949).

Generally, experiences of phenomena will stimulate actions (Reber et al., 1998). Hence, the process of judgement creation will allow individuals to (i) form an understanding of their environment, (ii) play a critical role in the way the individual interacts with the wider society (van Rullen and Koch, 2003), and (iii) inform on expressed judgements of events.

Studies suggest that variations exist among different project stakeholders in how project outcomes are judged (Jiang et al., 2009; Toor and Ogunlana, 2010; Turner and Zolin, 2012; Davis, 2013). Perhaps what is most interesting is that such judgements may change over the lifecycle of projects (Pinto and Prescott, 1988). A number of reasons have been cited in the literature for such variations including sometimes conflicting and multiple interpretations of project requirements (Klein and Jiang, 2001; Jiang et al., 2009).

A review of the extensive project management literature however appears to suggest that although a number of scholars have focused on understanding how role differences impact on the decision judgements of project stakeholders (see for example Jiang et al., 2009; Toor and Ogunlana, 2010; Savolainen et al., 2012: Beringer et al., 2013; Davis, 2013), only very limited research has focused on understanding how demographic differences impact on such decision criteria. This study seeks to address this gap in literature. 
Since judgement formation forms the basis of decisions (Child, 1972; Schuler, 1980), it is important that project team members have a consistent understanding of likely decision judgements that may be held by other members of the project team.

Cognitive management literature (Hambrick and Mason, 1984; George and Chattopadhyay, 2002) suggests that not only will the mental models of managers influence how decisions are made, but that demographic variables (e.g. role, age and gender) will serve as moderators for these models.

\subsection{Capturing expressed decision judgements}

In addition to studying the impact of several factors on decision judgements, we also considered the possibility of revisions to explicit and expressed decision judgements of projects and when, during the project lifecycle, such revisions are most likely to be made. Underpinning our measurement of expressed decision judgements are earlier studies undertaken by Churchill and Surprenant (1982) and Brown et al. (2008) on the disconfirmation of expectations, which suggests that whenever an individual's experience of an event does not meet their expectations, their general satisfaction levels will fall, resulting in disappointment. By extending this theory to decision-making criteria, we propose that:

- A practitioner's decision judgement of a project will be determined by the extent to which their expectations at a specific decision point (or project stage) are either met or not met.

- When a project is behaving in a manner that indicates that its fundamental performance criteria (time, cost, quality) will be met, individuals will develop a positive outlook regarding the project. However, when the project is behaving in a manner that indicates that these criteria will not be met, individuals will develop a negative outlook regarding the project.

- Differences between expected and actual performance at any given stage may cause a practitioner to revise or strengthen their expressed decision judgement of the project.

\section{Research hypothesis}


3.1 The 'role' demographic variable: Earlier studies (see Dearborn and Simon, 1958; Cohen and Ebbesen, 1979; Srivastva, 1983; Hambrick and Mason, 1984; Walsh, 1988) showed that the decision judgements of events held by individual managers are shaped by their expectations. Dearborn and Simon (1958), for example, suggested that visions of an organisation held by a manager were organised ordered in the mind according to function in the mind. In the same light, Srivastva (1983) found that the cognitive image of the organisation created by a manager guided not only their behaviour, but also the eventual decision judgements. Cohen and Ebbesen (1979) found that the goal orientation of an individual generally tends to inform, shape and guide the way they process information. This study posits that similar processes exist in projects: in other words, practitioners' decision judgements are likely to form and re-form as their expectations are shaped and honed by goal outcomes at different stages and milestones of the project.

Collectively, cognitive management literature on the role demographic (Hambrick and Mason, 1984; Stimpert et al., 2010) suggests a strong influence of both work experience and career roles on the cognitive models of managers. In effect, the literature suggests that decision making which is based on selective decision judgements (see section 2.1) may be mitigated by prior knowledge and skills developed from experience, i.e. tacit knowledge. Most importantly, scholars (Markoczy, 1997; Priem et al., 1999) suggest that selective decision judgements are influences by past experiences born from both social learning and job (organisational) conditioning within specific managerial environments.

From a project management perspective, if, as argued above, the activities are themselves determined by role, then it is highly plausible that project management practitioners could have arrived at various decision judgements of the project at different 'decision points' within the project lifecycle. Further, roles not only reflect the information available to each practitioner but also their ability or expertise to understand the information. For example, the information available to project managers is likely to be greater than that held by other stakeholders. Similarly, whereas a project manager may immediately understand the impact of an event on project success, it may not be as clear to the uninitiated project end-user. The 'decision point' could be indicative of when a practitioner 'buys into' a project. These differences point towards likely disparities in the judgement on what stage in the lifecycle is important and, by implication, the dominant activities associated with that stage in the lifecycle. Thus our first research hypothesis is: 
H1a: The likelihood of a practitioner forming a judgement of the project at a stage of the lifecycle is associated with the practitioner's main project role.

3.2 The 'gender' demographic variable: A review of extant literature on the effect of gender differences in managerial decision making appears inconclusive (Kidwell et al., 1987; Powell and Ansic, 1997; Klenke, 2003; Foschi and Valenzuela, 2012). In some cases, some studies such as those of Johnson and Powell (1994) and Powell and Ansic (1997) reported that there were no major differences emanating from gender differences in managerial decision making. On the other hand, both social theories of gender (see Davidson and Freudenburg, 1996; Gustafson, 1998) and economic salience theories (Stern et al., 1993) show that men and women generally hold different decision judgements of risk. More crucially, Hoffman (1974) and Feather (1975) found that gender impacted on success and failure judgements; while more recently, Foschi and Valenzuela (2012) provided evidence to suggest that gender has a biasing effect on the evaluation of task results and competency assessments. In earlier project management scholarship, Lindgren and Packendorff (2006) suggested the existence of delimited gender-based project work practice. Differences were also found to exist in the distributions of men and women in different roles (Anderson et al., 2008). As a result, it is possible that gender interacts not only with the project role but also with the timing of when decision judgements on the project were formed. To test these effects, our second hypothesis is now presented:

H2a: The likelihood of a practitioner forming a judgement of the project at a stage of the lifecycle is associated with the practitioner's gender.

3.3 The 'age' demographic variable: In terms of the third moderating factor under examination, various studies (Smola and Sutton, 2002 and Mellahi and Guermat, 2004, for example) have examined the impact of age on managerial decision making. Research suggests the existence of a relationship between age and decision making. For example, studies by Czaja et al. (1995) found age to be a determinant on articulation of judgements made on task difficulty; studies by Obst et al. (2011) found age to be related to risk judgements. In line with these research studies, we also expect that judgement of project outcomes to be influenced by the age of project management practitioners. Therefore, our third hypothesis is presented as: 
H3a: The likelihood of a practitioner forming a judgement of the project at a stage of the lifecycle is associated with the age of the practitioner.

3.4 Revising decision judgement: Initial judgements of the project are likely to be uncertain so that, as the project progresses and more information surfaces, or the meaning of previously held information becomes more apparent, practitioners may revise their judgement criteria. Thus, the second part of the analysis was to repeat tests of the three hypotheses ( $\mathrm{H} 1 \mathrm{a}$ to $\mathrm{H} 3 \mathrm{a}$ ), this time examining the likelihood of a practitioner revising their judgement of the project outcome:

H1b: The likelihood of a practitioner revising a judgement of the project at a stage of the lifecycle is associated with the practitioner's main project role.

$H 2 b$ : The likelihood of a practitioner revising a judgement of the project at a stage of the lifecycle is associated with the practitioner's gender.

$H 3 b$ : The likelihood of a practitioner revising a judgement of the project at a stage of the lifecycle is associated with the practitioner's age.

\section{The research methodology}

To gather data on decision judgements, we employed a questionnaire (see Appendix A) to elicit the level of importance that practitioners attributed to a range of criteria related to project success. These measures were largely drawn from earlier work on project success by Ojiako et al. (2008). It is important at this juncture to highlight the non-aggregation of project 'success' and 'failure' in the development of the questionnaire. Since research (Mahring and Keil, 2008; Bharadwaj et al., 2009) suggests that neither concept is a mirror image of the other, we chose not to aggregate both concepts into what Fincham (2002, p. 1) had referred to as an 'objective' and 'polarized state or outcome'. This was done for very pragmatic reasons. Fincham (2002, p. 5) had suggested that attributions of 'success' and 'failure' can best be regarded as narratives in other words as 'thematic interpretations placed on a train of events'. Thus the aggregation and an emphasis on conceptual differences and consequences of project 'success' and 'failure' would have required that the measure(s) of decision-making criteria be drawn around either success or 
failure factors. Acknowledging Fincham's study, it would have been questionable to present such a list to survey respondents drawn from around the world, working across different projectoriented industries and performing different roles within project delivery.

The survey was administered by direct distribution utilising electronic professional project management networks and forums (PMI, APM, CIOB, RICS ${ }^{2}$, LinkedIn ${ }^{3}$, ISWorld and PICMET ${ }^{4}$ ). Data were collected between March and December, 2011.

A total of 1313 surveys were returned but 58 were rejected due to errors or incompleteness, leaving 1255 usable responses. Table 1 shows the distribution of the respondents. The respondents' ages ranged from 18 to 74, with the average being 36 years. As we explain below, the data were analysed as categorical variables in a hierarchical log-linear model. As such, age- naturally a continuous variable with a wide range, was first recoded into two categories. The categories were 'younger' if the respondent's age was less than or equal to the sample median of the age of 32 years, and 'older' if not. It can be argued that the use of median-splits is arbitrary and may lead to loss of information about variations in age in each of the two groups. However, our search of the literature did not reveal the existence of more natural or more meaningful ways of splitting the practitioners by age as would be the case, for example, if we were sampling from the general population where natural, meaningful age groups such as 'infant', 'young adult' and 'retired' exist and are often used. In the absence of such evidence, we chose to use median-splits because they are the simplest, most parsimonious way to categorise respondents by age. Similarly, initial inspection of the dataset showed ten frequently occurring project roles. The proportions of respondents in some roles were much smaller than others. For example, 29\% were project managers but less than one per cent worked as a project assistant. In the analysis of categorical data, it is generally an accepted practice, where possible, to combine categories with very low frequencies with others. In this case, the researchers decided to combine categories with very low frequencies with others that represent, based on the judgement of the researchers, very similar roles. This resulted in the roles shown in Table 1. It can be seen in Table 1(a) that men 64\% represent a much higher proportion of the respondents than women (36\%). Whereas nearly equal proportions of men were categorised as

\footnotetext{
${ }^{2}$ APM (Association for Project Management), RICS (Royal Institute of Chartered Surveyors) and CIOB (Chartered Institute of Building), are all professional institutions.

${ }^{3}$ PMI (Project Management Institute), APM (Association for Project Management), RICS (Royal Institute of Chartered Surveyors) and CIOB (Chartered Institute of Building), are all professional institutions; PICMET, the Portland International Center for Management of Engineering and Technology and ISWorld form one of the largest IS/IT management professional forums; LinkedIn and Facebook are both social networks.

${ }^{4}$ PICMET, the Portland International Center for Management of Engineering and Technology and ISWorld form one of the largest IS/IT management professional forums; LinkedIn and Facebook are both social networks.
} 
'older' or 'younger', there were significantly more women in the 'younger' group. Turning to the project roles, the most apparent difference is that there are larger proportions of men in both the project manager and director/consultant roles.

\section{[INSERT TABLE 1 ABOUT HERE]}

The data used for this study comprise, first, variables collected from the survey on the demographic characteristics of project practitioners, viz a viz project role with which they had had the most experience, gender and age, and second, data collected on practitioners' likelihood to form or revise decision judgements on the project outcome at different lifecycle stages: (i) conception, (ii) when a milestone is reached, (iii) at the point of handover, (iv) when the project ends following final signoff by the client/customer, (v) when the project is operational ${ }^{5}$, and (vi) when the project is decommissioned. This question was then repeated by asking how likely they were to revise their decision judgements on project outcomes across the six stages in the project lifecycle. On both questions, practitioners could respond by selecting from ' 0 ' ='Not applicable', '1' = 'Very unlikely', '2' = 'Unlikely', '3’ ='Likely' or '4' ='Very likely'.

\section{Data analysis and results}

\subsection{Preliminary Correlational Analysis of Likelihoods to form or revise decision judgements}

Project lifecycle stages are constructs (see for example, Pinto and Prescott, 1988). They do not exist as natural, discrete states that can be clearly identified and distinguished from each other. There are likely to be similarities between different stages in the lifecycle, particularly in contiguous stages that have overlapping activities. The likelihoods of practitioners forming or revising a decision judgement at different stages in the lifecycle may therefore be related, with the direction and level of the correlation indicative of similarities/dissimilarities between stages. If this is the case, then to investigate whether a particular type of practitioner is more likely to form or

\footnotetext{
${ }^{5}$ The project stages were primarily based on the Associate of Project Management Body of Knowledge (2006, $5^{\text {th }}$ Edition; p. 81), which identifies operations to include 'on-going support and maintenance of the project deliverables'. This definition had been provided to respondents as part of the instructions to the survey.
} 
revise a decision judgement at a given stage in the lifecycle, it is necessary to control for the interactions of the likelihoods themselves, i.e. to treat them as related and not independent.

Thus, the first part of the analysis investigated the possibility of correlations among the likelihoods to form and revise decision judgements. Excluding all ‘not applicable’ responses (using pairwise elimination), we calculated Kendall's tau $b$ correlation coefficients between the likelihood to form a decision judgement at different stages in the lifecycle and then, separately, the likelihood to revise the decision judgement. The correlation matrices are shown in Table 2. It can be seen that most of the correlation coefficients are significant at the 0.05 p-value level. This suggests that the likelihood of forming or revising a decision judgement at a particular stage in the life-cycle is significantly associated with the likelihood of doing so at other stages in the life-cycle. Most of the coefficients are positive, indicating similarities between stages. Based on the size of the coefficient, the strongest association and, by implication, the strongest similarity is likely to be between the operational and decommissioned stages in the lifecycle.

A small number of the coefficients were insignificant, indicating independence. Others were significant but negative, indicating dissimilarity. These included the likelihood of forming a decision judgement

- $\quad$ at the conception stage and at the end;

- between when a milestone is reached and when the project is operational; and

- between when a milestone is reached and the project is decommissioned.

The size of the negative relationship between the latter pair suggests these are the most dissimilar stages with respect to practitioners forming an initial decision judgement. Similarly, there appear to be no associations between the likelihoods of revising a decision judgement at the conception stage and the end, the conception and operational stages, the conception and decommissioned stages, when a milestone is reached and the project is operational, and between reaching a milestone and the decommissioned stage.

Although these correlations do not hold for all pairs of stages in the lifecycle, in general, the correlational analysis suggests that the likelihood of a practitioner forming or revising a decision judgement about success or failure at any particular stage in the project lifecycle is likely to be related to the likelihood of them doing so at other stages in the lifecycle, i.e. we should not assume independence. 


\section{[INSERT TABLE 2 ABOUT HERE]}

\subsection{Hierarchical Log-linear Modelling}

To test all six hypotheses, i.e. explore the effect of role, age and gender on practitioners' likelihood to form or revise decision judgements at different stages in the project lifecycle, a loglinear modelling in SAS9.2 was conducted. Log-linear modelling is an appropriate technique for categorical data such as ours (see for example Agresti, 2002). For each project lifecycle stage, 'not applicable' responses were excluded from data analysis, i.e. treated as missing values. Prescreening showed very small frequencies of some categories. Therefore to obtain meaningful results, the remaining responses were recoded into 'likely' if the original response had been 'likely' or 'very likely'; and into 'unlikely' if it had been neither. Age, in its initial form, was not a categorical variable: to include it in the log-linear model, we categorised the values into 'younger' if the value was less than or equal to the sample median of age (32) and 'older' if not.

The log-linear models were created hierarchically, starting with a base (null hypothesis) model assuming no interaction between any of the variables and incrementing the amount of interaction between variables at each stage. This hierarchical modelling process was created first for $H 1 a$ to $H 3 a$ (formation of initial decision judgements) and then repeated for $H 1 b$ to $H 3 b$ (revision of decision judgements). Table 3 below shows the model fit summaries of the hierarchical log-linear models. Although log-linear models do not have a target or 'dependent' variable, for convenience in Table 3, the variables representing the formation or revision of decision judgements at different stages in the life-cycle are referred to as 'dependents' and age, gender and project role as 'independents'.

\section{[INSERT TABLE 3 ABOUT HERE]}

The results generated equivalent models for both the formation and revision of decision judgements. In both cases, it was clear that the variables should not be treated as independent (modelling stage 1). As shown in Table 3, at each stage the additional interaction increased the fit for the data. For both types of hypotheses (formation or revision of decision judgements), the 
models at stage 4 (allowing for all pair-wise interactions) were selected as our final models even though the chi-square value at this point remains statistically significant; an indication that higherlevel interaction models can provide improved fit for the data. There were two reasons for this decision: (i) higher-level interaction models are a lot less parsimonious but also (ii) they allow for two-way interactions between the variables which is sufficient to test our hypothesis.

\subsection{Effect of Role, Gender and Age on likelihood to form or revise decision judgements}

Table 3 shows the interactions of the variables that attained statistical significance. To save space, non-significant effects are not shown in Table 3. The log-linear results are consistent with the correlational analysis (section 4.1 above). They show that there are significant interactions among some of the 'dependent' variables. When all other two-way and one-way effects are taken into account, the results in Table 3 suggest that the following associations involving age are statistically significant: age and the formation of decision judgements at the milestone stage and handover stage; and age and the revision of decision judgements at the operational stage. Project role is significantly associated with the formation of decision judgements at the conception, milestone and decommissioned stages. Similar to age, project role is also significantly associated with the revision of decision judgements at the operational stage. In contrast, the results suggest that gender is not significantly associated with the formation of decision judgements at any stage in the project life-cycle but it is associated with the revision of decision judgements at the project end-stage.

\section{[INSERT TABLE 4 ABOUT HERE]}

Table 5 shows the exponentiated parameters of each effect. Each exponentiated parameter value can be seen as a multiplier representing the number of times the observed cell value is greater than (or less than) the value that would have been expected in the cell under the null hypothesis of independence. For example, the parameter value of conception by role of 1.27 (in Table 5a) can be interpreted as indicating that the number of directors/consultants who said they were 'likely' to form a decision judgement at the conception stage is $127 \%$ higher than would have been expected 
if the variables had been independent. In Table 5, we have presented only the results of interest to us, i.e. the parameter estimates of the statistically significant (based on the results in Table 4) twoway associations of gender, age and role with the likelihood to form or revise decision judgements at each of the six project lifecycle stages.

\section{[INSERT TABLE 5 ABOUT HERE]}

The results in Table 5a indicate that there are significantly fewer than expected (84\%) older (than 32 years) project practitioners who are likely to form judgements at the milestone stage; whereas there are significantly more (113\%) of the same age group who are likely to form a judgement at the handover stage. Table $5 \mathrm{~b}$ suggests that older project practitioners are significantly less likely (86\%) to change their previous decision judgement at the operational stage. These results lend support to both hypotheses $H 3 a$ and $H 3 b$. Turning to project role, the results suggest that project directors or consultants are significantly more likely to form a judgement at the conception (127\%) and decommissioned stages (120\%); but significantly less so at the milestone stage (69\%). Project support or board members are also significantly less likely to form a judgement at the milestone stage (86\%). Of the other role groups, the results suggest that project managers are strongly significantly more likely (152\%) to form a decision judgement at the milestone stage. This may reflect the golden triangle effect, by which project managers have been historically appraised and which, it appears, remains difficult for project management practitioners to dissociate from. The results also suggest that project role could be a significant differentiator when it comes to the likelihood of revising previous decision judgements at the operational stage: whilst project directors or consultants are less likely (86\%) to revise their judgements at this stage, project managers (136\%) and project support or board members are more likely to do so (123\%). These results support hypotheses $H 1 a$ and $H 1 b$. Although gender is significantly associated with the likelihood to revise decision judgements at the project end-stage (see Table $4 \mathrm{~b}$ ), the results in Table 5b show that in fact the observed number of men (and women) who are likely to change their minds at this stage does not reach statistical significance. Thus we can conclude that neither hypothesis $H 2 a$ nor $H 2 b$ is supported by the results.

As summarised in Table 6, the results support most of our hypotheses. 


\section{[INSERT TABLE 6 ABOUT HERE]}

\section{Discussion}

The results show that older project practitioners are unlikely to form an initial decision judgement about the project until the handover stage is reached. This suggests a tendency for older practitioners to reserve judgement on their decision of a project until late in the project lifecycle, after most of the activities have been completed. Thus, it is likely that older, more experienced practitioners, with more exposure to social learning and job (organisational) conditioning, will have more tacit knowledge and be less likely to form an early judgement that may affect decision making. This leads to a more stable longer term view of a project based on business outcomes rather than a view subject to more immediate project performance metrics. The fulfilment of business outcomes is unlikely to become apparent early in the project. This more measured approach could lead to better judgements as more information is available and consequently more effective decision making. On the other hand, if used indiscriminately, it could lead to continued commitment to failing projects. We therefore could posit that older (and by implication more experienced) project management practitioners may tend to base their decisions more on business and commercial benefits compared to traditional measures of project performance such as time, cost and quality.

Of the different roles, there is a very strong chance that project managers will form a judgement of the project when a milestone is reached. This suggests that milestones are of particular importance to project managers in terms of the points of formation and revision of their judgement of a project. The corollary of this is that the setting of the milestones themselves could be critical because it is at each milestone that project managers are most likely to review their judgements of a project. A positive or negative judgement at any given milestone may influence the decision taken by the project manager. Project managers also appear very likely to revise previous judgements once a project is operational. This contrasts sharply with project directors or consultants who are very unlikely to form a judgement at the milestone stage but are very likely to do so at the conception stage or the decommissioned stage, which suggests that these are the dominant stages in the lifecycle when the assessment of success or failure may be critical for them. 
Unless a convincing project plan is proposed, project directors or consultants may not buy into it and the project may lose their support. This is also important in the balance of a risk-adjusted project portfolio with a goal of achieving business unit efficiency. Since participation increases stakeholdership, the participation of directors and consultants at the conception stage should be considered critical.

It is interesting that of all the stages in the lifecycle, it was only at the operational stage that we observed significant differences among the different types of practitioners (by age and role) in their likelihood to revise their judgements of project success or failure. This may mean that it is only at the operational stage that the level of information available is sufficient for them to form a clearer assessment of whether the project has met its objectives. This can be contrasted with the lack of significant differences in the revision of such decisions at the end of the project or at decommissioned stages. Possibly, between the operational stage and, later, at the end or decommissioned stages, no significant changes typically occur to warrant further revisions.

Our results did not show any significant gender effect. It should be mentioned, however, that gender and role strongly interact, as do age and role. The results suggest that women are significantly under-represented in the 'project manager' role, a result which replicates previously observed levels of unequal distributions of women and men in different roles in project management. The interaction of age and role can be considered reasonable, with older (more experienced) practitioners more likely to occupy director or consultant roles.

\section{Conclusion}

This study investigated how project role and demographic differences (age and gender) impacted on the the formation and revision of decision judgements of practitioners over the project lifecycle. Earlier studies (Pinto and Prescott, 1988) had found that the relative importance of critical success factors of projects changed significantly over the lifecycle of a project. The study found that the likelihood of a practitioner forming or revising a decision judgement about a project at any one stage in the project lifecycle was likely to be related to their project role and age, but not to their gender. It also emerged from the study that the likelihood of forming or revising decision judgements was very similar across both the operational and decommissioned stages in the lifecycle. 
A possible implication of this finding may be gleaned from a study undertaken by He and Mittal in 2007, which explored the explored the impact of decisions and project stage on commitment escalation. They found that information requirements greatly influenced resource commitment, particularly at the initial stages of a project; while at the project completion stages, the desire to complete a project was the main driver influencing the commitment of resources to projects. This then implies that information has the greatest salience at the initial stages of a project - thus the demand for higher resources to be allocated to these stages. Based on this, the recognition of strong similarities between the operational and decommissioned stages in the project lifecycle will minimise an escalation of commitment, particularly at the intersection of the completion of the operational stages of a project and the commencement of the decommissioning stages. Such awareness will allow practitioners to focus their attention on the most salient factors of the project.

As expected, the study was not without limitations. Three main limitations are highlighted. Firstly, it is acknowledged that the study did not examine the driver for decision judgement differences emanating, for example, from notions of complexity among project practitioners. In terms of the second limitation, in the questionnaire, respondents were not provided with the opportunity to address project success/failure factors that were not mentioned in the survey but could have existed in some industry- or project-types. The third limitation of the paper was that context was not taken into consideration during the analysis of the data.

These limitations, however, offers scholars considerable opportunities for further studies. For example, future studies may seek to examine how more specialist (non-standard) project success/failure factors may impact on the formation and revision of project decision judgements. Extending this, future studies may focus not necessarily on examining the existence of judgement gaps between project stakeholders but on how, for example, consonance in terms of a number of project parameters such as requirements, performance measures, project goals and business needs may be achieved in order to ensure that the distinct vested interests of various project stakeholders are maintained. Future research may also seek more comprehensive understanding of the determinant human factors that influence these decision judgements across the project lifecycle by examining, for example, the role of context on the formation and revision of project decision judgements. Further studies may also examine the nature of decision judgements in projects noting that practitioners may hold more than one decision judgement of an event when making a decision (Fowler and Walsh, 1999). On this occasion, such studies may seek to examine - for example - 
how multiple decision judgements in projects may be balanced. This question may perhaps be addressed through experimental manipulation.

\section{References}

Agresti, A., 2002. Categorical Data Analysis. Second ed. John Wiley \& Sons. Hoboken, NJ.

Anderson, S., Pearo, L., Widener, S., 2008. Drivers of Service Satisfaction: Linking Customer Satisfaction to the Service Concept and Customer Characteristics. Journal of Service Research 10 (4), 365-381.

Beringer, C., Jonas, D., Kock, A., 2013. Behavior of internal stakeholders in project portfolio management and its impact on success. International Journal of Project Management 31 (6), 830-846.

Bharadwaj, A., Keil, M., Mahring, M., 2009. Effects of information technology failures on the market value of firms. Journal of Strategic Information Systems18 (2), 66-79.

Brown, S., Venkatesh, V., Kuruzovich, J., Massey, A., 2008. Expectation confirmation: An examination of three competing models. Organizational Behaviour and Human Decision Processes 105 (1), 52-66.

Bruner, J., Postman, L., 1949. On the perception of incongruity: A paradigm. Journal of Personality, 18, 206-223.

Cheng, M., Dainty, A., Moore, D., 2005. What makes a good project manager? Human Resource Management Journal 15 (1), 25-37.

Cheesman, J., Merikle, P., 1986. Distinguishing conscious from unconscious perceptual processes. Canadian Journal of Psychology 40, 343-367.

Child, J., 1972. Organization Structure, Environment, and Performance-The Role of Strategic Choice. Sociology 6, 1-22.

Churchill, G., Surprenant, C., 1982. An investigation into the determinants of customer satisfaction. Journal of Marketing Research 19, 491-504.

Clarke, N., 2010. Emotional intelligence and its relationship to transformational leadership and key project manager competences. Project Management Journal 28 (3), 1-10.

Cohen, C., Ebbesen, E., 1979. Observational goals and schema activation: A theoretical framework for behaviour perception. Journal of Experimental Social Psychology 15, 305-329. 
Czaja, S., Sharit, J., Nair, S., 1995. Age Differences in Perception of Workload for a Computer Task. Proceedings of the Human Factors and Ergonomics Society 39 (2), 129-133.

Davidson, D., Freudenburg, W., 1996. Gender and Environmental Concerns: A Review and Analysis of Available Research. Environmental Behaviour 28, 302-339.

Davis, K., 2013. Different stakeholder groups and their perceptions of project success. International Journal of Project Management, http://dx.doi.org/10.1016/j.ijproman.2013.02.006, In Press.

Dearborn, D., Simon, H., 1958. Selective perceptions: A note on the departmental identification of executives. Sociometry 21, 140-144.

Feather, N., 1975. Positive and negative reactions to male and female success and failure in relation to perceived status and sex-typed appropriateness of occupations. Journal of Personality and Social Psychology 31, 536-538.

Fincham, R., 2002. Narratives of Success and Failure in Systems Development. British Journal of Management 13, 1-14.

Foschi, M., Valenzuela, J., 2012. Who is the better applicant? Effects from gender, academic record, and type of decision. Social Science Research 41 (4), 949-964.

Fowler, A., Walsh, M., 1999. Conflicting perceptions of success in an information systems project. International Journal of Project Management 17 (1), 1-10.

Freeman, W., 2003. A neurobiological theory of meaning in perception. Part 1, Information and meaning in nonconvergent and nonlocal brain dynamics. International Journal of Bifurcation and Chaos 13, 2493-2511.

George, E., Chattopadhyay, P., 2002. Do differences matter? Understanding demography-related effects in organizations. Australian Journal of Management 27, 47-56.

Gustafson, P., 1998. Gender Differences in Risk Perception: Theoretical and Methodological Perspectives. Risk Analysis 18(6), 805-811.

Hambrick, D., Mason, P., 1984. Upper echelons: The organization as a reflection of its top managers. Academy of Management Review 9, 193-206.

He, X., Mittal, V., 2007. The effect of decision risk and project stage on escalation of commitment. Organizational Behavior and Human Decision Processes 103 (2), 225-237.

Hodgson, D., 2002. Disciplining the Professional: The Case of Project Management. Journal of Management Studies 39 (6), 803-821. 
Hoffman, L., 1974. Fear of success in males and females. Journal of Consulting and Clinical Psychology 41, 353-358.

Jiang, J., Klein, G., Wu, S., Liang, T., 2009. The relation of requirements uncertainty and stakeholder perception gaps to project management performance. Journal of Systems and Software 82 (5), 801-808.

Johnson, J.E.V., Powell, P.L., 1994. Decision Making, Risk and Gender: Are Managers Different? British Journal of Management 5, 123-138.

Kidwell, J., Stevens, R., Bethke, A., 1987. Differences in ethical perceptions between male and female managers: Myth or reality? Journal of Business Ethics 6, 489-493.

Klein, G., Jiang, J., 2001. Seeking consonance in information systems. Journal of Systems and Software 56 (2), 195-202.

Klenke, K., 2003. Gender influences in decision-making processes in top management teams. Management Decision 41 (10), 1024-1034.

Koskinen, K., Pihlanto, P., Vanharanta, H., 2003. Tacit knowledge acquisition and sharing in a project work context. International Journal of Project Management 21 (4), 281-290.

Lindgren, M., Packendorff, J., 2006. What's New in New Forms of Organizing? On the Construction of Gender in Project-Based Work. Journal of Management Studies 43 (4), 841866.

Mahring, M., Keil, M., 2008. Information technology project escalation: a process model. Decision Sciences 39 (2), 239-272.

Marcel, A., 1983a. Conscious and unconscious perception: Experiments on visual masking and word recognition. Cognitive Psychology 15, 197-237.

Marcel, A., 1983b. Conscious and unconscious perception: An approach to the relations between phenomenal experience and perceptual processes. Cognitive Psychology 15, 238-300.

Markoczy, L., 1997. Measuring beliefs: Accept no substitutes. Academy of Management Journal 40, 1128-1142.

Mellahi, K., Guermat, C., 2004. Does age matter? An empirical examination of the effect of age on managerial values and practices in India. Journal of World Business 39, 199-215.

Obst, P., Armstrong, K., Smith, S., Banks, T., 2011. Age and gender comparisons of driving while sleepy: Behaviours and risk perceptions. Transportation Research Part F: Traffic Psychology and Behaviour 14 (6), 539-542. 
Ojiako, GU., Johansen, D., Greenwood, D., 2008. A qualitative re-construction of the project failure concept. Industrial Management and Data Systems 108 (3), 405-417.

Pinto, J., Prescott, J., 1988. Variations in critical success over the stages in the project life cycle. Journal of Management 14 (1), 5-18.

Powell, M., Ansic, D., 1997. Gender differences in risk behaviour in financial decision making: an experimental analysis. Journal of Economic Psychology 18 (6), 605-628.

Priem, R., Lyon, D., Dess, G., 1999. Inherent limitations of demographic proxies in top management team heterogeneity research. Journal of Management 25, 935-953.

Prinz, W., 1997. Perception and action planning. European Journal of Cognitive Psychology 9, 129-154.

Reber, R., Winkielman, P., Schwarz, N., 1998. Effects of perceptual fluency on affective judgments. Psychological Science 9, 45-48.

Savolainen, P., Ahonen, J., Richardson, I., 2012. Software development project success and failure from the supplier's perspective: A systematic literature review. International Journal of Project Management 30 (4), 458-469.

Schacter, D., 1990. Introduction to Implicit memory: Multiple perspectives. Bulletin of the Psychonomic Society 28, 338-340.

Schuler, R., 1980. A Role and Expectancy Perception Model of Participation in Decision Making. Academy of Management Journal 23 (2), 331-340.

Smola, K., Sutton, C., 2002. Generational differences: Revisiting generational work values for the new millennium. Journal of Organizational Behaviour, 23, 363-382.

Srivastva, S., 1983. The Executive Mind. Jossey-Bass, San Francisco.

Stern, P., Dietz, T., Kalof, L., 1993. Value Orientations, Gender, and Environmental Concern. Environmental Behaviour 25, 322-348.

Stimpert, J., Duhaime, I., Chesley, J., 2010. Learning to Manage a Large Diversified Firm. Journal of Leadership \& Organizational Studies 17(4), 411-425.

Toor, S., Ogunlana, S., 2010. Beyond the 'iron triangle': stakeholder perception of key performance indicators (KPIs) for large-scale public sector development projects. International Journal of Project Management 28, 228-236. 
Turner, J., Zolin, R., 2012. Forecasting success on large projects: developing reliable scales to predict multiple perspectives by multiple stakeholders over multiple time frames. Project Management Journal 43 (5), 87-99.

van Rullen, R., Koch, C., 2003. Is perception discrete or continuous? Trends in Cognitive Sciences 7, 207-13.

Walsh, J., 1988. Selectivity and Selective Perception: An Investigation of Managers' Belief Structures and Information Processing. Academy of Management Journal 31 (4), 873-896.

Table 1: Distribution of Project Practitioners by Age, Role and Gender

Table 1a: Distribution of Gender by Age (Frequency Missing = 5)

\begin{tabular}{|l|l|l|l|}
\hline & Female & Male & Total \\
\hline $\begin{array}{l}\text { Older }(>32 \\
\text { years) }\end{array}$ & $190(15.2 \%)$ & $407(32.56 \%)$ & $597(47.76 \%)$ \\
\hline $\begin{array}{l}\text { Younger }(=<32 \\
\text { years) }\end{array}$ & $259(20.72 \%)$ & $394(31.52 \%)$ & $653(52.24 \%)$ \\
\hline Total & $449(35.92 \%)$ & $801(64.08 \%)$ & $1250(100 \%)$ \\
\hline
\end{tabular}

Table 1b: Distribution of Project Roles by Age

\begin{tabular}{|l|l|l|l|l|l|l|}
\hline & $\begin{array}{l}\text { Director } \\
\text { Consultant } \\
\text { (Project } \\
\text { Director or } \\
\text { Project } \\
\text { Consultant) }\end{array}$ & $\begin{array}{l}\text { End User } \\
\text { Sponsor } \\
\text { Client } \\
\text { (Project } \\
\text { End-user, } \\
\text { Sponsor or } \\
\text { Client) }\end{array}$ & $\begin{array}{l}\text { Little PM } \\
\text { Experience } \\
\text { Unspecified } \\
\text { Role (Little } \\
\text { or no PM } \\
\text { experience, } \\
\text { or Role was } \\
\text { not } \\
\text { Specified) }\end{array}$ & $\begin{array}{l}\text { Project } \\
\text { Manager }\end{array}$ & $\begin{array}{l}\text { Support } \\
\text { Board } \\
\text { Member } \\
\text { (Project } \\
\text { Support or } \\
\text { Project } \\
\text { Group Board } \\
\text { Member) }\end{array}$ & Total \\
\hline $\begin{array}{l}\text { Older }(>32 \\
\text { years) }\end{array}$ & $\begin{array}{l}188 \\
(14.98 \%)\end{array}$ & $99(7.89 \%)$ & $46(3.67 \%)$ & $\begin{array}{l}176 \\
(14.02 \%)\end{array}$ & $89(7.09 \%)$ & $\begin{array}{l}598 \\
(47.65 \%)\end{array}$ \\
\hline $\begin{array}{l}\text { Younger }(=<32 \\
\text { years) }\end{array}$ & $102(8.13 \%)$ & $118(9.4 \%)$ & $\begin{array}{l}136 \\
(10.84 \%)\end{array}$ & $\begin{array}{l}186 \\
(14.82 \%)\end{array}$ & $115(9.16 \%)$ & 657 \\
\hline Total & $\begin{array}{l}180.35 \%) \\
(23.11 \%)\end{array}$ & $\begin{array}{l}217 \%) \\
(17.29 \%)\end{array}$ & $\begin{array}{l}182(14.5 \%) \\
(28.84 \%)\end{array}$ & $\begin{array}{l}204 \\
(16.25 \%)\end{array}$ & $1255(100 \%)$ \\
\hline
\end{tabular}

Table 1c: Distribution of Project Roles by Gender (Frequency Missing = 5) 


\begin{tabular}{|c|c|c|c|c|c|c|}
\hline & $\begin{array}{l}\text { Director } \\
\text { Consultant } \\
\text { (Project } \\
\text { Director or } \\
\text { Project } \\
\text { Consultant) }\end{array}$ & $\begin{array}{l}\text { End User } \\
\text { Sponsor } \\
\text { Client } \\
\text { (Project End } \\
\text { User, } \\
\text { Sponsor or } \\
\text { Client) }\end{array}$ & $\begin{array}{l}\text { Little PM } \\
\text { Experience } \\
\text { Unspecified } \\
\text { Role (Little } \\
\text { or no PM } \\
\text { experience } \\
\text { or Role was } \\
\text { not } \\
\text { Specified) }\end{array}$ & $\begin{array}{l}\text { Project } \\
\text { Manager }\end{array}$ & $\begin{array}{l}\text { Support } \\
\text { Board } \\
\text { Member } \\
\text { (Project } \\
\text { Support or } \\
\text { Project } \\
\text { Group Board } \\
\text { Member) }\end{array}$ & Total \\
\hline Female & 105 (8.4\%) & $96(7.68 \%)$ & $88(7.04 \%)$ & 83 (6.64\%) & 77 (6.16\%) & $\begin{array}{l}449 \\
(35.92 \%)\end{array}$ \\
\hline Male & 185 (14.8\%) & $120(9.6 \%)$ & $91(7.28 \%)$ & $\begin{array}{l}279 \\
(22.32 \%)\end{array}$ & $\begin{array}{l}126 \\
(10.08 \%)\end{array}$ & $\begin{array}{l}801 \\
(64.08 \%)\end{array}$ \\
\hline Total & $290(23.2 \%)$ & $\begin{array}{l}216 \\
(17.28 \%)\end{array}$ & $\begin{array}{l}179 \\
(14.32 \%)\end{array}$ & $\begin{array}{l}362 \\
(28.96 \%)\end{array}$ & $\begin{array}{l}203 \\
(16.24 \%)\end{array}$ & $1250(100 \%)$ \\
\hline
\end{tabular}

Table 2: Correlations (Kendall's tau b) of Likelihoods to form and revise views of Success or Failure

Table 2a: Correlations of Likelihoods to form views

Conception Milestone Handover End Operational

Conception

\begin{tabular}{|c|c|c|c|c|}
\hline Milestone & $.234^{* *}$ & & & \\
\hline Handover & $.062^{*}$ & $.353^{* *}$ & & \\
\hline End & $-.080^{* *}$ & $.231^{* *}$ & $.421^{* *}$ & \\
\hline Operational & -.029 & $-.110^{* *}$ & .031 & $.240^{* *}$ \\
\hline Decommissioned & -.045 & $-.153^{* *}$ & $.081^{* *}$ & $.200^{* *}$ \\
\hline
\end{tabular}

Table 2b: Correlations of Likelihoods to revise views

Conception Milestone Handover End Operational

Conception

$.283^{* *}$

Milestone

$.182^{* *}$

$.365^{* *}$

Handover

$-.002$

$.157^{* *}$

$.475^{* *}$

Operational

.000

.029

$.391^{* *}$

$.525^{* *}$

Decommissioned

.022

.014

$.303^{* *}$

$.485^{* *}$

$.628^{* *}$

**. Correlation is significant at the 0.01 level (2-tailed).

*. Correlation is significant at the 0.05 level (2-tailed).

Table 3: Hierarchical Log-linear model fitting 
Table 3a- Log-Linear Model Fit: Effect of Age, Gender and Project Role on Likelihood of Forming Views of Success

\begin{tabular}{|c|c|c|c|c|c|c|c|c|}
\hline $\begin{array}{l}\text { Model } \\
\text { Stage }\end{array}$ & Description & DF & $\begin{array}{l}\text { Likelih } \\
\text { ood } \\
\text { Ratio } \\
\text { (Chi- } \\
\text { Square) }\end{array}$ & P-value & $\begin{array}{l}\text { Step } \\
\text { Compa } \\
\text { risons }\end{array}$ & $\mathrm{DF}$ & $\begin{array}{l}\text { Chi- } \\
\text { square } \\
\text { Change }\end{array}$ & P-value \\
\hline Stage 1 & $\begin{array}{l}\text { All variables } \\
\text { orthogonal }\end{array}$ & $\begin{array}{l}33 \\
6\end{array}$ & 813.35 & $\begin{array}{l}1.510 \mathrm{E} \\
-41\end{array}$ & N/A & N/A & N/A & N/A \\
\hline Stage 2 & $\begin{array}{l}\text { Interactions between } \\
\text { all 'Dependents'; and } \\
\text { each dependent with } \\
\text { independent variables }\end{array}$ & $\begin{array}{l}32 \\
1\end{array}$ & 448.18 & $\begin{array}{l}3.355 E \\
-06\end{array}$ & $\begin{array}{l}\text { Stage } 1 \\
\text { to } 2\end{array}$ & 15 & 365.17 & $\begin{array}{l}1.404 \mathrm{E} \\
-68\end{array}$ \\
\hline Stage 3 & $\begin{array}{l}\text { All-two interactions } \\
\text { except between the } \\
\text { independents with each } \\
\text { other }\end{array}$ & $\begin{array}{l}28 \\
5\end{array}$ & 278.48 & $\begin{array}{l}5.976 \mathrm{E} \\
-01\end{array}$ & $\begin{array}{l}\text { Stage } 2 \\
\text { to } 3\end{array}$ & 36 & 169.7 & $\begin{array}{l}3.032 \mathrm{E} \\
-19\end{array}$ \\
\hline Stage 4 & $\begin{array}{l}\text { All two-way } \\
\text { interactions }\end{array}$ & $\begin{array}{l}27 \\
6\end{array}$ & 225.44 & $\begin{array}{l}9.884 \mathrm{E} \\
-01\end{array}$ & $\begin{array}{l}\text { Stage } 3 \\
\text { to } 4\end{array}$ & 9 & 53.04 & $\begin{array}{l}2.872 \mathrm{E} \\
-08\end{array}$ \\
\hline
\end{tabular}

Table 3b- Log-Linear Model Fit: Effect of Age, Gender and Project Role on Likelihood of Revising Views of Success

\begin{tabular}{|c|c|c|c|c|c|c|c|c|}
\hline $\begin{array}{l}\text { Model } \\
\text { Stage }\end{array}$ & Description & DF & $\begin{array}{l}\text { Likelih } \\
\text { ood } \\
\text { Ratio } \\
\text { (Chi- } \\
\text { Square } \\
\text { ) }\end{array}$ & $\begin{array}{l}\mathrm{P} \text { - } \\
\text { value }\end{array}$ & $\begin{array}{l}\text { Step } \\
\text { Compa } \\
\text { risons }\end{array}$ & DF & $\begin{array}{l}\text { Chi- } \\
\text { square } \\
\text { Chang } \\
\text { e }\end{array}$ & $\begin{array}{l}\mathrm{P} \text { - } \\
\text { value }\end{array}$ \\
\hline Stage 1 & $\begin{array}{l}\text { All variables } \\
\text { orthogonal }\end{array}$ & 402 & 961.73 & $\begin{array}{l}8.001 \mathrm{E} \\
-48\end{array}$ & N/A & N/A & N/A & N/A \\
\hline Stage 2 & $\begin{array}{l}\text { Interactions between } \\
\text { all 'Dependents'; and } \\
\text { each dependent with } \\
\text { independent variables }\end{array}$ & 387 & 494.73 & $\begin{array}{l}1.683 \mathrm{E} \\
-04\end{array}$ & $\begin{array}{l}\text { Stage } \\
1 \text { to } 2\end{array}$ & 15 & 467 & $\begin{array}{l}5.323 \mathrm{E} \\
-90\end{array}$ \\
\hline Stage 3 & $\begin{array}{l}\text { All-two interactions } \\
\text { except between the } \\
\text { independents with } \\
\text { each other }\end{array}$ & 351 & 353.45 & $\begin{array}{l}4.533 \mathrm{E} \\
-01\end{array}$ & $\begin{array}{l}\text { Stage } \\
2 \text { to } 3\end{array}$ & 36 & 141.28 & $\begin{array}{l}2.096 \mathrm{E} \\
-14\end{array}$ \\
\hline Stage 4 & $\begin{array}{l}\text { All two-way } \\
\text { interactions }\end{array}$ & 342 & 298.96 & $\begin{array}{l}9.549 \mathrm{E} \\
-01\end{array}$ & $\begin{array}{l}\text { Stage } \\
3 \text { to } 4\end{array}$ & 9 & 54.49 & $\begin{array}{l}1.523 \mathrm{E} \\
-08\end{array}$ \\
\hline
\end{tabular}

Table 4- Formation and Revision of Views: Maximum Likelihood Analysis of Variance

Table 4a- Formation Views: Maximum Likelihood Analysis of Variance

$\begin{array}{llll}\text { Source } & \text { DF } & \text { Chi-Square } & \text { Pr > ChiSq } \\ \text { Conception * } & 1 & 6.24 & 0.0125 \\ \text { Conception By Role** } & 4 & 15.31 & 0.0041 \\ \text { Milestone By Conception** } & 1 & 15.65 & 0.00001 \\ \text { Milestone By Age** } & 1 & 17.97 & 0.00001 \\ \text { Milestone By Role** } & 4 & 50.34 & 0.00001\end{array}$




$\begin{array}{llll}\text { End * } & 1 & 4.39 & 0.0361 \\ \text { End By Handover** } & 1 & 14.82 & 0.0001 \\ \text { End By Operational** } & 1 & 18.86 & 0.00001 \\ \text { End By Decommissioned** } & 1 & 23.24 & 0.00001 \\ \text { Handover** } & 1 & 26.02 & 0.00001 \\ \text { Handover By Milestone** } & 1 & 7.68 & 0.0056 \\ \text { Handover By Age* } & 1 & 4.26 & 0.0391 \\ \text { Operational** } & 1 & 7.71 & 0.0055 \\ \text { Decommissioned By Operational** } & 1 & 14.3 & 0.0002 \\ \text { Decommissioned By Role* } & 4 & 10.93 & 0.0273 \\ \text { Gender* } & 1 & 5.58 & 0.0181 \\ \text { Gender By Role** } & 4 & 15.34 & 0.0041 \\ \text { Age } * & 1 & 5.9 & 0.0151 \\ \text { Age By Role** } & 4 & 28.51 & 0.00001 \\ \text { Likelihood Ratio } & 276 & 225.44 & 0.9884\end{array}$

Table 4b-Revision of Views: Maximum Likelihood Analysis of Variance

\begin{tabular}{|c|c|c|c|}
\hline Source & $\mathrm{DF}$ & Chi-Square & Pr $>$ ChiSq \\
\hline Conception** & 1 & 9.94 & 0.0016 \\
\hline Milestone** & 1 & 35.71 & 0.00001 \\
\hline Milestone By Conception** & 1 & 44.95 & 0.00001 \\
\hline End By Milestone** & 1 & 9.18 & 0.0024 \\
\hline End By Handover** & 1 & 26.8 & 0.00001 \\
\hline End By Operational** & 1 & 18.41 & 0.00001 \\
\hline End By Decommissioned** & 1 & 20.03 & 0.00001 \\
\hline End By Gender* & 1 & 5.7 & 0.017 \\
\hline Handover** & 1 & 25.3 & 0.00001 \\
\hline Handover By Conception** & 1 & 10.06 & 0.0015 \\
\hline Handover By Milestone** & 1 & 6.95 & 0.0084 \\
\hline Operational By Age** & 1 & 13.11 & 0.0003 \\
\hline Operational By Role** & 4 & 45.51 & 0.00001 \\
\hline Decommissioned By Operational** & 1 & 73.59 & 0.00001 \\
\hline Gender** & 1 & 6.7 & 0.0096 \\
\hline Gender By Role** & 4 & 17.15 & 0.0018 \\
\hline Age By Role** & 4 & 32.52 & 0.00001 \\
\hline Likelihood Ratio & 342 & 298.96 & 0.9549 \\
\hline
\end{tabular}

Table 5- Parameter Estimates: Formation of Initial Views and Revision of Views

Table 5a- Parameter Estimates: Formation of Initial Views

$\begin{array}{lll}\text { Parameter 1 } & \text { Response Categories } & \text { Exp_Estimate } \\ \text { Conception BY Role } & \text { Likely Director Consultant } & 1.27^{* *} \\ \text { Conception BY Role } & \text { Likely Support Board Member } & 0.86^{*} \\ \text { Milestone BY Age } & \text { Likely Older } & 0.84^{* *} \\ \text { Milestone BY Role } & \text { Likely Director Consultant } & 0.69^{* *} \\ \text { Milestone BY Role } & \text { Likely Project Manager } & 1.52^{* *}\end{array}$



Handover BY Age
Likely Older
$1.13^{*}$
Decommissioned BY Role
Likely Director Consultant
$1.2^{*}$
Table 5b- Parameter Estimates: Formation of Initial Views
Parameter 1
Response Categories
Exp_Estimate
Operational BY Age
Likely Older
$0.86^{* *}$
Operational BY Role
Likely Director Consultant
$0.63 * *$
Operational BY Role
Likely Project Manager
$1.36 * *$
Operational BY Role
Likely Support Board Member 1.23*
* $X^{2}$ Statistic of parameter estimate significant at 0.05 p-value level
$* * X^{2}$ Statistic of parameter estimates significant at 0.01 p-value level

Table 6: Data Analysis Results according to each hypothesis
Hypothesis
Result
H1a: The likelihood of a practitioner forming a view of success or failure at each stage in
Supported
the project lifecycle is associated with his/her main project role.
H2a: The likelihood of a practitioner forming a view of success or failure at each stage in
the project lifecycle is associated with his/her gender.
H3a: The likelihood of a practitioner forming a view of success or failure at each stage in the project lifecycle is associated with his/her age.
H1b: The likelihood of a practitioner revising a current or previous view of success or failure at each stage in the project lifecycle is associated with his/her age.
H2b: The likelihood of a practitioner revising a current or previous view of success or failure at each stage in the project lifecycle is associated with his/her gender.
H3b: The likelihood of a practitioner revising a current or previous view of success or failure at each stage in the project lifecycle is associated with his/her age.
Not Supported
Supported
Supported
Not Supported
Supported

Appendix A: The questionnaire

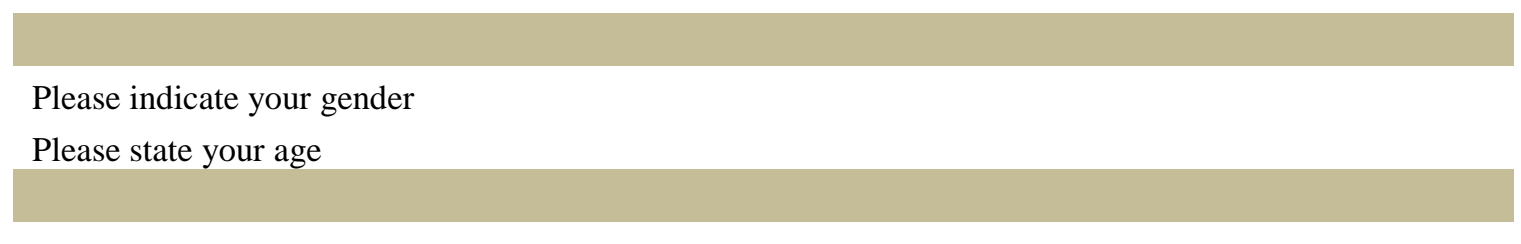

Question 12

Below are some project success/failure factors. For each factor, state the level that comes closest to matching your view of its importance in a current or recent project that you were involved in 


\begin{tabular}{|c|c|c|c|c|c|}
\hline Success and failure factor & $\begin{array}{l}\text { Very } \\
\text { Unimportant }\end{array}$ & Unimportant & $\begin{array}{l}\text { Neither } \\
\text { Important } \\
\text { nor } \\
\text { Unimportant }\end{array}$ & Important & $\begin{array}{l}\text { Very } \\
\text { Important }\end{array}$ \\
\hline \multirow{2}{*}{$\begin{array}{l}\text { Factor: Contribution to } \\
\text { business goals and/or } \\
\text { strategy. } \\
\text { (For example, the project } \\
\text { made a significant and } \\
\text { valuable contribution to } \\
\text { business goals and/or } \\
\text { strategy. Or, the project made } \\
\text { no contribution to business } \\
\text { goals and/or strategy.) }\end{array}$} & & & & & \\
\hline & & & & & \\
\hline \multicolumn{6}{|l|}{$\begin{array}{l}\text { Factor: Contribution to } \\
\text { society/community/economy. }\end{array}$} \\
\hline \multicolumn{6}{|l|}{$\begin{array}{l}\text { (For example, the project } \\
\text { made a significant and } \\
\text { valuable contribution to } \\
\text { society/community/economy. } \\
\text { Or, the project made no } \\
\text { contribution to } \\
\text { society/community/economy.) }\end{array}$} \\
\hline \multicolumn{6}{|l|}{$\begin{array}{l}\text { Factor: Achievement of } \\
\text { intended outcomes as defined } \\
\text { by the sponsor/owner/client. }\end{array}$} \\
\hline \multicolumn{6}{|l|}{$\begin{array}{l}\text { (For example, the project } \\
\text { achieved all its intended } \\
\text { outcomes as defined by the } \\
\text { sponsor/owner/client. Or, the } \\
\text { project achieved none of its } \\
\text { intended outcomes as defined } \\
\text { by the sponsor/owner/client.) }\end{array}$} \\
\hline $\begin{array}{l}\text { Factor: Planned and approved } \\
\text { project scope (including any } \\
\text { approved changes). }\end{array}$ & & & & & \\
\hline
\end{tabular}




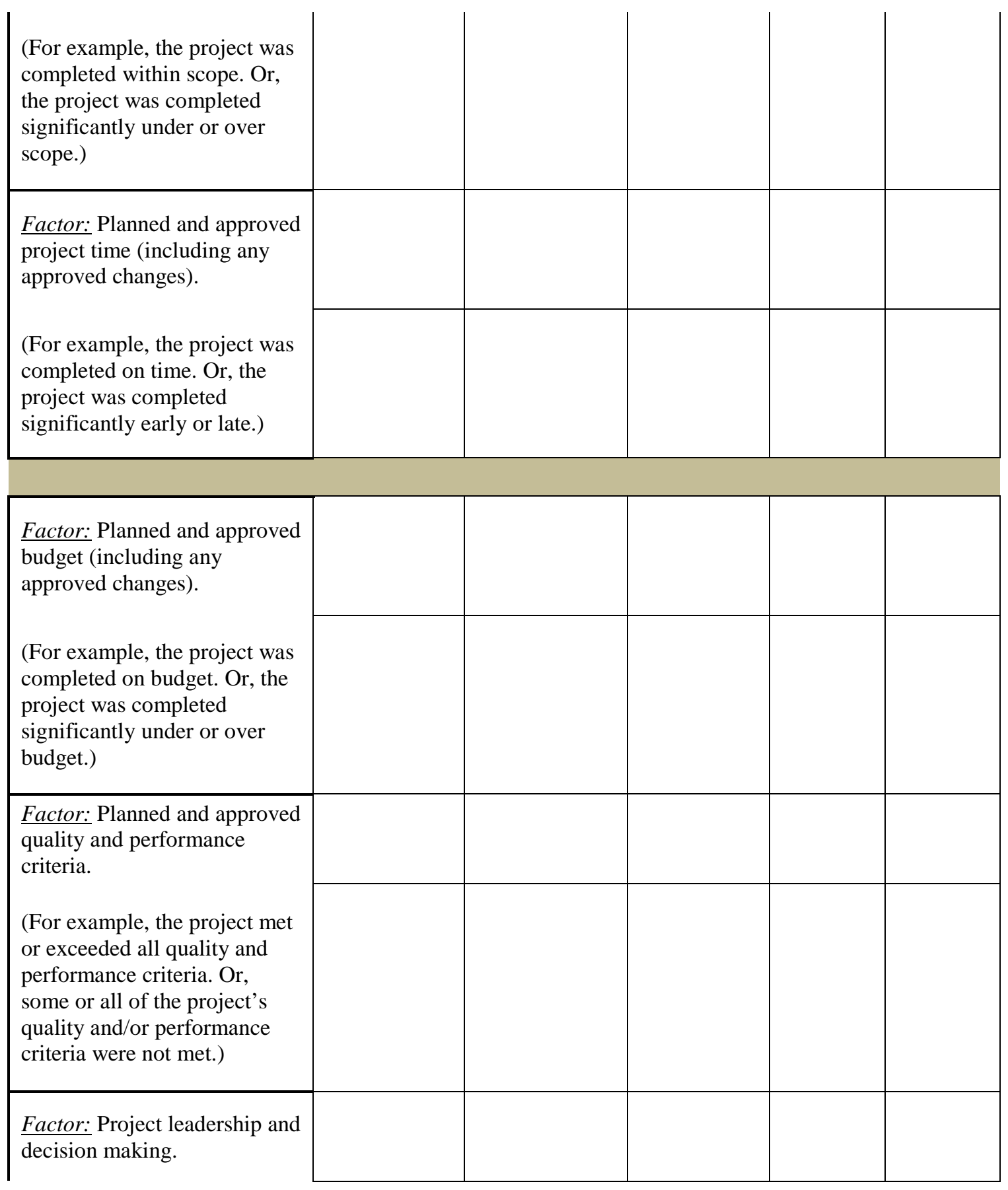


(For example, most stakeholders agree that project leadership and decision making were appropriate and effective. Or, most stakeholders agree that project leadership and decision making were neither appropriate nor effective.)

Factor: The project team.

(For example, the project team worked effectively and lessons were learned for future projects. Or, the project team did not work effectively and lessons were not learned for future projects.)

Factor: Communications, risk, and safety management.

(For example, communications, risk, and safety were effectively managed. Or, communications, risk and safety were poorly managed.)

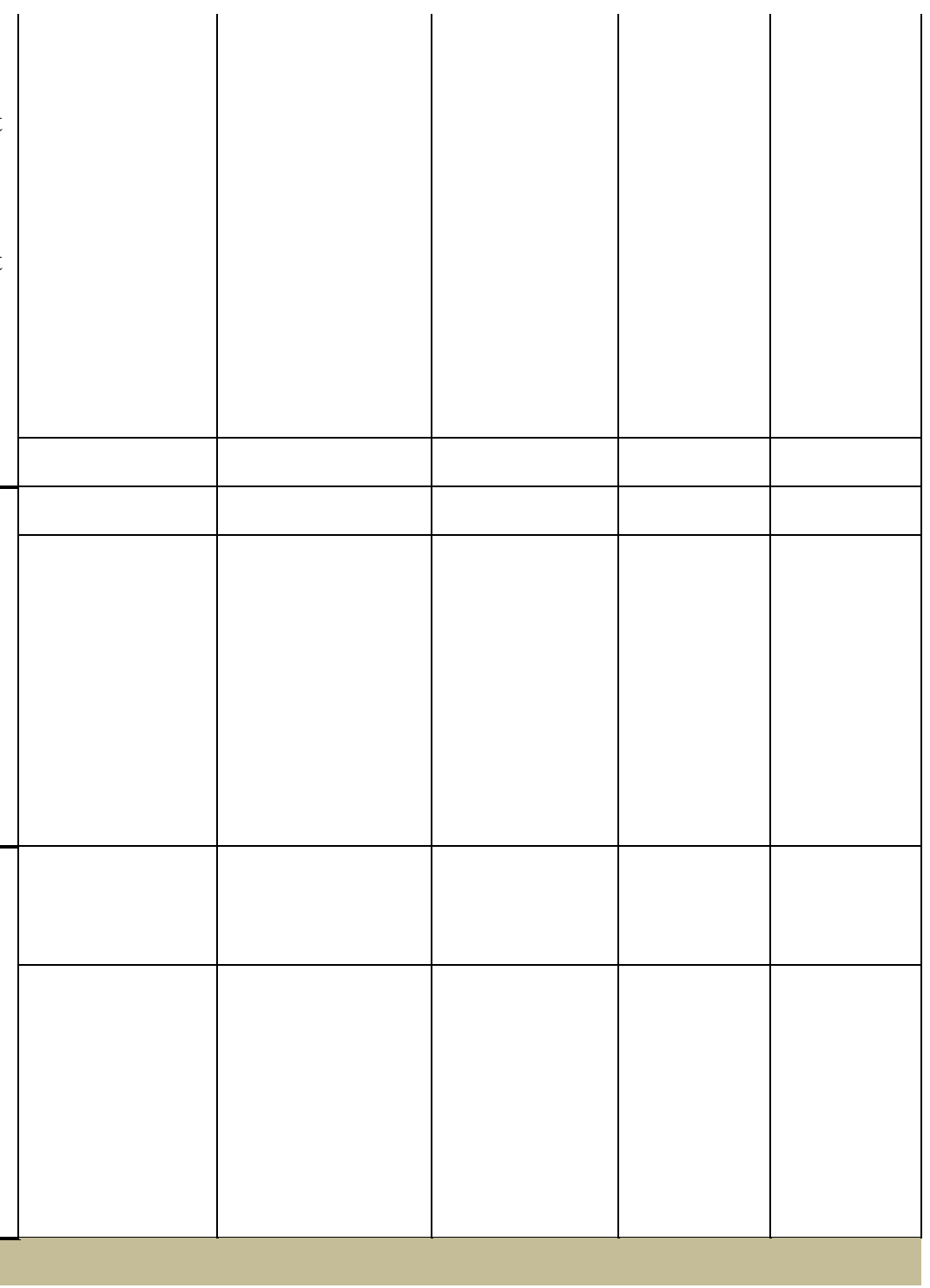

Question 13

For each project success/failure factor, please state how much the level of importance you indicated in question 12 above would change as a result of project context.

\begin{tabular}{|l|l|l|l|l|l|}
\hline Success and failure factor & Not at all & $\begin{array}{l}\text { A small } \\
\text { amount }\end{array}$ & $\begin{array}{l}\text { A fair } \\
\text { amount }\end{array}$ & $\begin{array}{l}\text { A large } \\
\text { amount }\end{array}$ & $\begin{array}{l}\text { A very } \\
\text { large } \\
\text { amount }\end{array}$ \\
\hline $\begin{array}{l}\text { Contribution to business goals } \\
\text { and/or strategy. }\end{array}$ & & & & & \\
\hline $\begin{array}{l}\text { Contribution to } \\
\text { society/community/economy. }\end{array}$ & & & & & \\
\hline $\begin{array}{l}\text { Achievement of intended } \\
\text { outcomes as defined by the } \\
\text { sponsor/owner/client. }\end{array}$ & & & & & \\
\hline
\end{tabular}




\begin{tabular}{|l|l|l|l|l|l|}
$\begin{array}{l}\text { Planned and approved project } \\
\text { scope (including any } \\
\text { approved changes). }\end{array}$ & & & & & \\
\hline $\begin{array}{l}\text { Planned and approved project } \\
\text { time (including any approved } \\
\text { changes). }\end{array}$ & & & & & \\
\hline $\begin{array}{l}\text { Planned and approved budget } \\
\text { (including any approved } \\
\text { changes). }\end{array}$ & & & & & \\
\hline $\begin{array}{l}\text { Planned and approved quality } \\
\text { and performance criteria. }\end{array}$ & & & & & \\
\hline $\begin{array}{l}\text { Project leadership and } \\
\text { decision making. }\end{array}$ & & & & & \\
\hline The project team. & & & & & \\
\hline $\begin{array}{l}\text { Communications, risk, and } \\
\text { safety management. }\end{array}$ & & & & & \\
\hline
\end{tabular}

Question 14

Below are some project aspects and participants: These may or may not influence the level of project success/failure factors. For each influencer, state the level that comes closest to your view of its impact on success/failure factors.

\begin{tabular}{|c|c|c|c|c|c|}
\hline Success and failure factor & Not at all & $\begin{array}{l}\text { A small } \\
\text { amount }\end{array}$ & $\begin{array}{l}\text { A fair } \\
\text { amount }\end{array}$ & $\begin{array}{l}\text { A large } \\
\text { amount }\end{array}$ & $\begin{array}{l}\text { A very } \\
\text { large } \\
\text { amount }\end{array}$ \\
\hline \multicolumn{6}{|l|}{ Client or owner or sponsor } \\
\hline \multicolumn{6}{|l|}{ Project Manager } \\
\hline \multicolumn{6}{|l|}{ Other stakeholders } \\
\hline \multicolumn{6}{|l|}{ The internal environment } \\
\hline \multicolumn{6}{|l|}{ The external environment } \\
\hline \multicolumn{6}{|l|}{ Politics } \\
\hline \multicolumn{6}{|l|}{ Culture } \\
\hline \multicolumn{6}{|l|}{ Benchmarking } \\
\hline \multicolumn{6}{|l|}{ Clarity of objectives } \\
\hline \multicolumn{6}{|l|}{$\begin{array}{l}\text { End-user/customer } \\
\text { satisfaction }\end{array}$} \\
\hline \multicolumn{6}{|l|}{$\begin{array}{l}\text { Communication and } \\
\text { knowledge sharing }\end{array}$} \\
\hline \multicolumn{6}{|l|}{ Knowledge sharing } \\
\hline \multicolumn{6}{|l|}{ Human resources } \\
\hline \multicolumn{6}{|l|}{ Planning and management } \\
\hline Contractual arrangements & & & & & \\
\hline
\end{tabular}




\begin{tabular}{|l|l|l|l|l|l|}
\hline $\begin{array}{l}\text { Project leadership and } \\
\text { decision making }\end{array}$ & & & & & \\
\hline The project team & & & & & \\
\hline Risk management & & & & & \\
\hline
\end{tabular}

Question 15

Can project success be graded; (a) No, in my view a project either succeeds or fails (b) Yes, it is possible to grade the success or failure of a project so that, for example, some projects are very successful, some are partially successful, some are partially unsuccessful, some are very unsuccessful, etc.

Question 16

A project participant may form an initial perception about whether the project will be successful at different stages in the project life cycle.

For each of the project stages below, state how likely you are to form a perception about success or failure of the project.

\begin{tabular}{|l|l|l|l|l|l|}
\hline Success and failure factor & $\begin{array}{l}\text { Very } \\
\text { Unlikely }\end{array}$ & Unlikely & $\begin{array}{l}\text { Not } \\
\text { applicable }\end{array}$ & Likely & $\begin{array}{l}\text { Very } \\
\text { Likely }\end{array}$ \\
\hline Planning stage & & & & & \\
\hline $\begin{array}{l}\text { When a major milestone is } \\
\text { reached }\end{array}$ & & & & & \\
\hline Handover stage & & & & & \\
\hline After the project is completed & & & & & \\
\hline $\begin{array}{l}\text { After the project has been } \\
\text { operational for some time }\end{array}$ & & & & & \\
\hline $\begin{array}{l}\text { After the project has been } \\
\text { decommissioned }\end{array}$ & & & & & \\
\hline
\end{tabular}

Question 17

Once formed, perceptions of project success or failure may change later on. For each of the stages of a project below, state how likely it is that your perceptions of success or failure formed at that stage will change later on.

\begin{tabular}{|l|l|l|l|l|l|}
\hline Success and failure factor & $\begin{array}{l}\text { Very } \\
\text { Unlikely }\end{array}$ & Unlikely & $\begin{array}{l}\text { Not } \\
\text { applicable }\end{array}$ & Likely & $\begin{array}{l}\text { Very } \\
\text { Likely }\end{array}$ \\
\hline Planning stage & & & & & \\
\hline $\begin{array}{l}\text { When a major milestone is } \\
\text { reached }\end{array}$ & & & & & \\
\hline Handover stage & & & & \\
\hline
\end{tabular}




\begin{tabular}{|l|l|l|l|l|l|} 
After the project is completed & & & & & \\
\hline $\begin{array}{l}\text { After the project has been } \\
\text { operational for some time }\end{array}$ & & & & & \\
\hline $\begin{array}{l}\text { After the project has been } \\
\text { decommissioned }\end{array}$ & & & & & \\
\hline
\end{tabular}

Question 18

It is possible that differences in the perceptions of success or failure of projects among participants may be caused by certain characteristics of the participants or the circumstances.

For each circumstance/participant listed below, state the level that comes closest to matching your view of how important is its influence on how perceptions of failure or success are formed.

\begin{tabular}{|l|l|l|l|l|l|}
\hline Success and failure factor & $\begin{array}{l}\text { Very } \\
\text { Unimportant }\end{array}$ & Unimportant & $\begin{array}{l}\text { Neither } \\
\text { Important } \\
\text { nor } \\
\text { Unimportant }\end{array}$ & Important & $\begin{array}{l}\text { Very } \\
\text { Important }\end{array}$ \\
\hline $\begin{array}{l}\text { Differences between } \\
\text { stakeholders }\end{array}$ & & & & & \\
\hline Differences in interests & & & & & \\
\hline $\begin{array}{l}\text { Conflicting views (e.g., } \\
\text { understanding of the problem } \\
\text { to be solved) }\end{array}$ & & & & & \\
\hline $\begin{array}{l}\text { Nature of the project (e.g., } \\
\text { complexity) }\end{array}$ & & & & & \\
\hline $\begin{array}{l}\text { Type of project (e.g., } \\
\text { construction, IT, etc.) }\end{array}$ & & & & & \\
\hline Size of the project & & & & & \\
\hline
\end{tabular}

Question 19

Which of the following best describes the majority of your experience of project management? (i) Project Consultant (ii) Project End User (iii) Project Sponsor (or client) of the project (iv) Project Manager (v) Project Director (vi) Project Support (vi) Steering Committee or Project Board member (vii) Member of the public (viii) Little or no experience of Project Management 